Anim. Reprod., v.13, n.1, p.3-6, Jan./Mar.

\title{
Growth and reproductive traits of purebred and crossbred Romanov lambs in Eastern Anatolia
}

\author{
M. Kutluca Korkmaz ${ }^{1}$, E. Emsen ${ }^{2}$ \\ ${ }^{1}$ Ispir Hamza Polat Vocational School, Ataturk University, 25900, Ispir, Erzurum, Turkey. \\ ${ }^{2}$ Department of Animal Science, Faculty of Agriculture, Ataturk University, 25240, Erzurum, Turkey.
}

\begin{abstract}
The performance of purebred Romanov (R) lambs and crossbred lambs of Romanov and Morkaraman (M) breeding were compared under a semi-intensive production system. The $\mathrm{M}$ breed is a fattailed breed native to Eastern Anatolia, Turkey. Analyses were conducted on data from 168 lambs produced from $\mathrm{R}$ and $\mathrm{M}$ ewes through laparoscopic artificial insemination (LAI) with the semen of pure $\mathrm{R}$ and F1 RxM rams. Pure R, F1 (RxM, 1/2 R), and $1 / 4 \mathrm{R}$ (RxM x M backcross) lambs were produced. The F1 and $1 / 4 \mathrm{R}$ lambs had heavier $(\mathrm{P}<0.05)$ birth weights than $\mathrm{R}$ lambs while $\mathrm{F} 1$ and $\mathrm{R}$ lambs had heavier $(\mathrm{P}<0.05)$ weaning weights than $1 / 4 \mathrm{R}$ lambs. The three groups of lambs differed $(\mathrm{P}<0.05)$ from each other for age of puberty in males and females where with $\mathrm{R}$ lambs were the youngest, F1 lambs were intermediate, and $1 / 4 \mathrm{R}$ lambs were the oldest. The percentage of ewe lambs that exhibited estrus within one year of age was higher $(\mathrm{P}<0.01)$ for $\mathrm{R}(100 \%)$ and $\mathrm{F} 1(67 \%)$ lambs than for $1 / 4 \mathrm{R}$ lambs $(43 \%)$. In conclusion, improvement in growth and early reproductive traits can be obtained from crossbreeding the fat-tailed Morkaraman breed with the Romanov breed.
\end{abstract}

Keywords: crossbreeding, Romanov.

\section{Introduction}

Sheep breeding is one of the most important agricultural sectors in Turkey, and is ranked second after cattle for meat production. Production characteristics of sheep breeds in Turkey are relatively low, especially reproductive efficiency. The Morkaraman is a predominant dual purpose fat-tailed sheep breed of the eastern region of Turkey and it comprises $22 \%$ of the total sheep population. The age at first lambing in Morkaraman sheep is around 24 months and produces about 1.05 lambs per ewe (Ocak et al., 2009). The most important factor determining the success of sheep production is reproductive efficiency, which is the net biological accomplishment of all reproductive activities i.e. puberty, oestrus, ovulation, fertilization, implantation, gestation and successful lambing, as well as survival and growth after birth. For any trait affecting efficiency of meat production, there is useful genetic variation among sheep breeds worldwide. It has been documented that sheep numbers have been declining throughout the world over the last five years, resulting in decreased sheep meat production and a resultant shortage of supply. There is evidence that demand in the short-term will not be met by the major exporters (New Zealand and Australia; Morris, 2009). To overcome the meat shortage in developing countries, indigenous sheep with low reproductive efficiency can be crossbred with prolific breeds, which will adapt well in the target region.

The Romanov is known as one of the most prolific breeds, along with Finnsheep, Booroola Merino, Barbados Blackbelly and British Milk Sheep. Crossbreeding with Romanov sheep has been practiced in several countries of the Mediterranean basin (Ricordeau et al., 1990) to take advantage of high lamb vigor and rapid growth rates. In Eastern Turkey, crossbreeding of fat tailed ewes with Romanov started in 2004 to increase prolificacy (Koycegiz et al., 2009). The reason to select the Romanov breed as a source of increasing reproductive efficiency by crossbreeding is due to the other advantages, such as high adaptability, suitability of being managed successfully in different systems (intensive, semi intensive and extensive) and higher survivability rates of its crossbred lambs, which are lacking in other prolific breeds. Moreover, there are differences in the coefficient of variation in litter size in prolific breeds, which are transmitted to their crossbred daughters; the Romanov breed is the least variable (Cupps, 1991). The aim of this study was to assess production traits of Romanov and compare them to crossbred lambs of different genotypes produced with crosses of Romanov and a local fat tailed-breed (Morkaraman) of sheep raised in eastern Anatolia.

\section{Material and Methods}

\section{Flock Description}

This experiment was conducted at the Ataturk University, Sheep Research and Application Farm. The ewe breeds (2-5 years old) involved were Morkaraman $(\mathrm{M} ; \mathrm{n}=66)$, the local fat tailed breed of the region, and Romanov ( $\mathrm{R} ; \mathrm{n}=38$ ), which originated in Russia and 
was established as a nucleus flock in Turkey via embryo transfer with frozen embryos imported from Canada. Clinically normal, adult ewes were laparoscopically inseminated and pregnant ewes were included in the study. Ram genotypes used in the LAI program were as follows: crossbreeding with Romanov rams (No. of rams $=4$; No. of Morkaraman ewes $=50$ ) and $1 / 2$ Romanov Morkaraman rams (No. of rams $=4$; No. of Morkaraman ewes $=16$ ). Romanov ewes were also inseminated with Romanov semen by LAI (No. of rams $=2$; No of Romanov ewes $=38$ ). Native Morkaraman ewes were selected for crossbreeding in the LAI program due to the inability of short tail Romanov rams to lift the fat tail of the ewe.

\section{Traits}

Growth traits evaluated were those measured from the start of-lambing to weaning of the lambs, which occurred at 8 weeks of age. Litter size at birth, sex of lambs, birth weight and weaning weight of lambs were recorded.

After weaning, ewe lambs and ram lambs were separated into two groups and observed for sexual activity to determine pubertal age. Ewe lambs were checked for estrus twice daily with vasectomized rams, and those showing behavioral signs of estrus were examined with a laparoscope for ovulation 6 days after the onset of estrus. Ewe lambs were weighed when they reached puberty, which was determined by the onset of estrus accompanied by ovulation. On the other hand, sexual behavior of ram lambs was examined by using three teaser ewes in a pen and after observing manifestation of sexual behavior in ram lambs, semen was collected by electroejeculator and the presence of sperm confirmed by video microscope. Body weight and scrotal circumference were recorded at the time of first presence of viable spermatozoa in the ejaculate. Lamb survival rates were calculated from birth (0 days) to weaning (60 days).

\section{Feeding protocol}

All lambs were offered a complete creep diet (2.50 Mcal of ME kg-1 DM with $16 \%$ CP) by approximately 14 days of age. The average amount of creep feed consumed by the lambs was estimated at 100 $\mathrm{g} / \mathrm{h} /$ day. After 14 days of age lambs were offered ad libitum concentrate $\left(2.75 \mathrm{Mcal}\right.$ of ME $\mathrm{kg}^{-1} \mathrm{DM}$ with $12 \% \mathrm{CP}$ ) diet and $500 \mathrm{~g}$ dry grass hay/head/day.

\section{Statistical analysis}

The model from the growth traits included the effects of genotype, litter size and sex of the lambs, while reproductive traits included only the effect of genotype. Growth performance traits of ewe and ram lambs measured were birth and weaning weights, and survivability rate at weaning. Records for growth performance of lambs that were born and reproductive performance of lambs that were alive at weaning and pubertal ages were included in the analyses. For all traits analyzed, the 2- and 3-way interactions were included in the initial model. Interactions that were not significant $(\mathrm{P}>0.05)$ were subsequently removed from the final model.

The ewe lambs reproductive traits analyzed were age and body weight at puberty, percentage of ewes that showed estrus, and percentage of ewes that lambed, while ram lambs reproductive performance traits were age, body weight, and scrotal circumference at puberty. Data were analyzed by ANOVA using the GLM procedure (MINITAB). The difference between means was compared using the Duncan's multiple range tests. Survivability data was analyzed by chi-square $\left(\chi^{2}\right)$.

\section{Results}

Birth weights and weaning weights of lambs were significantly $(\mathrm{P}<0.01)$ different for Romanov lambs and crossbred lambs sired either with Romanov or F1 Romanov rams. Crossbred lambs were heavier at birth (F1: $3.38 \pm 0.23$ and $1 / 4 \mathrm{R}: 3.47 \pm 0.28 \mathrm{~kg}$ ) than $\mathrm{R}$ lambs $(2.50 \pm 0.21 \mathrm{~kg})$. Weaning weights were similar for R and F1 lambs, while $1 / 4$ Romanov lambs were significantly lighter than these two genotypes. Survival rates from birth to weaning were significantly different for the genotypes studied. Romanov lambs were recorded with a lower $(\mathrm{P}<0.05)$ survival rate compared to crossbred lambs. Birth type and sex were found significant for weaning weight but none of these factors affected survivability rates. Single born lambs were heavier $(\mathrm{P}<0.05)$ at birth, and quadruplets were lightest. However, lambs born as quadruplets are too few to include in a comparison (Table 1.)

The age at first presence of sperm, (onset of puberty) was significantly $(\mathrm{P}<0.01)$ different between breeds. Age at puberty averaged 112.5, 134.5 and 195.2 days in $\mathrm{R}, \mathrm{F} 1$ and $1 / 4 \mathrm{R}$ ram lambs, respectively. F1 ram lambs reached puberty at heavier $(\mathrm{P}<0.01)$ weights than $\mathrm{R}$ and $1 / 4 \mathrm{R}$ ram lambs. Even though there was a larger scrotal circumference in $\mathrm{R}$ and $\mathrm{F} 1$ lambs than $1 / 4$ $R$ lambs, this was not statistically significant (Table 2).

The percentage of ewe lambs showing the first sign of estrus within one year of age was significantly $(\mathrm{P}<0.01)$ different. All of the $\mathrm{R}$ ewe lambs were observed in estrus and the $1 / 2$ Romanov and $1 / 4$ Romanov ewe lambs followed, respectively. Average age at first estrus and weight at this age was significantly $(\mathrm{P}<0.01)$ different and Romanov ewe lambs were earliest to show first estrus at the lightest weight (Table 3). 
Kutluca Korkmaz and Emsen. Romanov lambs in Eastern Anatolia.

Table 1 . Least squares means \pm SE for weights and survival of lambs.

\begin{tabular}{lcccc}
\hline \multicolumn{1}{c}{ Lamb Genotype } & $\mathrm{n}$ & $\begin{array}{c}\text { Birth weight } \\
(\text { Mean } \pm \mathrm{SE})\end{array}$ & $\begin{array}{c}\text { Weaning weight } \\
(\text { Mean } \pm \text { SE) }\end{array}$ & $\begin{array}{c}\text { Survivability } \\
(\%)\end{array}$ \\
\hline Romanov (R) & 77 & $2.5 \pm 0.18^{\mathrm{a}}$ & $20.7 \pm 0.57^{\mathrm{a}}$ & 73 \\
F1 Romanov (F1) & 65 & $4.3 \pm 0.15^{\mathrm{b}}$ & $21.3 \pm 0.54^{\mathrm{a}}$ & 91 \\
Quarter Romanov (1/4 R) & 26 & $4.1 \pm 0.24^{\mathrm{b}}$ & $17.7 \pm 0.88^{\mathrm{b}}$ & 88 \\
& & $* *$ & & $* *$ \\
Litter Size & & & $21.9 \pm 0.48^{\mathrm{a}}$ & 88 \\
$\quad$ Single & 75 & $4.4 \pm 0.13^{\mathrm{a}}$ & $19.2 \pm 0.56^{\mathrm{b}}$ & 84 \\
$\quad$ Twin & 68 & $3.0 \pm 0.15^{\mathrm{b}}$ & $18.7 \pm 1.14^{\mathrm{b}}$ & 74 \\
$\quad$ Triplet & 21 & $2.4 \pm 0.30^{\mathrm{b}}$ & $15.5 \pm 2.78^{\mathrm{c}}$ & 83 \\
$\quad$ Quadruplet & 4 & $1.5 \pm 0.74^{\mathrm{c}}$ & $* *$ & $\mathrm{NS}$ \\
Sex & & $* *$ & $19.6 \pm 0.55^{\mathrm{a}}$ & 86 \\
$\quad$ Female & & & $21.2 \pm 0.49^{\mathrm{b}}$ & 78 \\
$\quad$ Male & 78 & $3.5 \pm 0.17$ & $*$ & $\mathrm{NS}$
\end{tabular}

Least squares means within a column followed by different letters differ $(\mathrm{P}<0.05)$; NS: $\mathrm{P}>0.05 ; *$ : $\mathrm{P}<0.05$; **: $\mathrm{P}<0.01$.

Table 2. Least squares means and standard errors of traits measured on ram lambs.

\begin{tabular}{lcccc}
\hline Lamb Genotype & $\mathrm{n}$ & $\begin{array}{c}\text { Age at puberty } \\
(\text { day) }\end{array}$ & $\begin{array}{c}\text { Body weight at puberty } \\
(\mathrm{kg})\end{array}$ & $\begin{array}{c}\text { Scrotum circumference at } \\
\text { puberty } \\
(\mathrm{cm})\end{array}$ \\
\hline Romanov (R) & 24 & $112.5 \pm 2.27^{\mathrm{a}}$ & $23.73 \pm 0.94^{\mathrm{a}}$ & $22.05 \pm 0.71$ \\
F1 Romanov (RM) & 32 & $134.5 \pm 2.00^{\mathrm{b}}$ & $28.67 \pm 0.77^{\mathrm{b}}$ & $22.24 \pm 0.58$ \\
Quarter Romanov (RMR) & 12 & $195.2 \pm 2.78^{\mathrm{c}}$ & $24.86 \pm 1.18^{\mathrm{a}}$ & $19.86 \pm 0.89$ \\
& & $* *$ & $* *$ & $\mathrm{NS}$ \\
\hline
\end{tabular}

Least squares means within a column followed by different letters differ $(\mathrm{P}<0.05)$; NS: $\mathrm{P}>0.05 ; * *: \mathrm{P}<0.01$.

Table 3. Least squares means and standard errors of traits measured on ewe lambs in their first year.

\begin{tabular}{lccccc}
\hline \multicolumn{1}{c}{ Lamb genotype } & $\mathrm{n}$ & $\begin{array}{c}\text { Age at puberty } \\
\text { (day) }\end{array}$ & $\begin{array}{c}\text { Body weight at } \\
\text { puberty } \\
(\mathrm{kg})\end{array}$ & $\begin{array}{c}\text { Percentage of ewes } \\
\text { showed estrus }\end{array}$ & $\begin{array}{c}\text { Percentage of } \\
\text { ewes lambed }\end{array}$ \\
\hline Romanov (R) & 27 & $164.5 \pm 9.70^{\mathrm{a}}$ & $26.1 \pm 0.80^{\mathrm{a}}$ & 100 & 96 \\
F1 Romanov (RM) & 24 & $255.6 \pm 11.27^{\mathrm{b}}$ & $37.10 \pm 0.93^{\mathrm{b}}$ & 67 & 57 \\
Quarter Romanov (RMR) & 11 & $319.7 \pm 29.10^{\mathrm{c}}$ & $38.67 \pm 2.39^{\mathrm{b}}$ & 43 & 33 \\
& & $* * * * *$ & $* *$ & $* *$
\end{tabular}

Least squares means within a column followed by different letters differ $(\mathrm{P}<0.05) ; * *: \mathrm{P}<0.01$.

\section{Discussion}

In general, birth weights of crossbred lambs were similar, whereas the fecund-type breed, Romanov, produced significantly lighter lambs. It has been well documented that lamb birth weights decrease as litter size increases. The litter size at birth in Romanov breeds was 2.01 and it was 1.3 and 1.6 for $\mathrm{F} 1$ and $1 / 4 \mathrm{R}$ lambs, respectively. In another study conducted by Freetly and Leymaster (2004), litter sizes in the Romanov were larger than in the other breeds and birth weight was decreased. It has been previously reported that the birth weights of Romanov-cross lambs were higher than those for local Morkaraman lambs (Koycegiz et al., 2009).

The Romanov breed had the highest lamb mortality (0.28) while that of the crossbreeds was the lowest (0.09-0.12). Maria and Ascaso (1999), working with Romanov ewes in Spain, reported similar results.
For the Romanov lambs mortality rates were $25 \%$, while for a synthetic type produced by crossing with Rasa Aregonesa mortality was $11 \%$. Survival rates observed for Romanov lambs were better than those observed by Fahmy (1996), who reported 2.86 lambs born per ewe, of which 0.52 were dead at birth. Similar results were published by Sierra (1985), who found mortality rates ranging from 19.4 to $21.1 \%$ within 2 days of parturition in a Romanov flock in Spain.

Reducing the generation interval is one method for increasing animal production. One way to reduce generation interval in a breeding program is to use animals for mating shortly after they reach puberty (Kridli et al., 2007a). Scrotal circumference has been shown to differ among breeds of sheep (Belibasaki and Kouimtzis, 2000), and is larger in crossbred than in purebred lambs. An earlier onset of puberty was achieved in F1 ram lambs and ewe lambs compared to 
those from $1 / 4 \mathrm{R}$, and decreasing the percentage of Romanov blood in crossbred lambs delayed the onset of puberty. Similar results were also reported by Greeff $e t$ al. (1993) in Romanov and Romanov $\times$ Dorper cross-bred ewes. Results of the study reported by Kridli et al. (2007b) indicated that crossbreeding fat tailed sheep with low reproductive performance with the Romanov breed improved reproductive parameters in the F1 crosses and the backcrossing decreased reproductive performance. The fact that not only age, but also body weight at puberty, differed among ram lamb and ewe lamb groups indicates that prolific breeds reach puberty at lighter weights.

Early sexual maturity is a desirable trait in intensive production systems. Ewes lambing for the first time at one year of age allow producers to cull infertile animals earlier and to distribute the maintenance costs of the ewe flock over a larger number of lambs. In the present study, F1 ewe lambs were approximately 9 weeks younger than $1 / 4 \mathrm{R}$ ewe lambs at their first estrus and $24 \%$ more $\mathrm{F} 1$ ewe lambs reached puberty within one year of age than $1 / 4 \mathrm{R}$ ewe lambs. Almost all of the Romanov (96\%) and $57 \%$ of F1 ewe lambs were one year of age at first lambing, indicating an ability to lamb during their first year without extending the breeding or lambing period of the flock. The earlier sexual maturity of the Romanov first cross ewes is supported by results from other countries. In Czechoslovakia, Jakubec (1977) reported for Romanov x Mutton Merino ewe lambs, in Canada for the Romanov X Dorset (Vesely and Swierstra, 1986), and in Israel for the Romanov $\mathrm{x}$ Awassi ewes (Goot et al., 1979).

In conclusion, differences between breeds of sheep in levels of performance for economically important traits are genetically based and can be exploited through the use of crossbreeding systems. The results of this study demonstrate the superiority of the Romanov over the $\mathrm{F} 1$ cross or $1 / 4 \mathrm{R}$ in reproductive performance. Morkaraman ewes inseminated with Romanov or F1 Romanov semen produced lambs with higher birth weights compared to R ewes. F1 ewe lambs reached sexual maturity earlier than $1 / 4 \mathrm{R}$ ewe lambs. The comparison of three different genotypes provides information to help producers identify breeds that will meet specific production requirements.

\section{Acknowledgments}

Authors acknowledge Dr Ileana Wenger for linguistic revision.

\section{References}

Belibasaki S, Kouimtzis S. 2000. Sexual activity and body and testis growth in prepubertal ram lambs of Friesland, Chios, Karagouniki and Serres dairy sheep in Greece. Small Rumin Res, 37:109-113.

Cupps PT. Reproduction in domestic animals.4th. ed. Academic Press Inc, San Diego, California; 1991:625pp.

Fahmy MH. 1996. Prolific Sheep. Wallingford, UK: CAB International. $560 \mathrm{pp}$.

Freetly HC, Leymaster KA. 2004. Relationship between litter birth weight and litter size in six breeds of sheep. J Anim Sci, 82:612-618.

Greeff JC, Langenhoven J, Wyma GA. 1993. Puberty and ovulation rate of Romanov, Dorper and their crosses during the first breeding season. S Afr J Anim Sci, 23:113-115.

Goot H, Eyal E, Folman Y, Foote WC. 1979. Contemporary comparisons between progeny by Finnish Landrace and Romanov rams out of Mutton Merino and Awassi ewes. Livest Prod Sci, 6:283-293.

Jakubec V. 1977. Productivity of crosses based on prolific breeds of sheep. Livest Prod Sci, 4:379-392.

Koycegiz F, Emsen E, Diaz CAG, Kutluca M. 2009. Effects of lambing season, lamb breed and ewe parity on production traits of fat tailed sheep and their lambs. $J$ Anim Vet Adv, 8:195-198.

Kridli RT, Abdullah AY, Shaker MM, Masa'deh MK. 2007a. Sexual activity and puberty in pure Awassi and crosses and backcrosses with Charollais and Romanov sheep breeds. NZ J Agric Res, 50:429-436.

Kridli RT, Momany Shaker M, Abdullah AY, Muwalla MM. 2007b. Sexual behaviour of yearling Awassi, Charollais $\times$ Awassi and Romanov $\times$ Awassi rams exposed to oestrous Awassi ewes. Trop Anim Health Prod, 39:229-235.

Maria GA, Ascaso MS. 1999. Litter size, lambing interval and lamb mortality of Salz, Rasa Aragonesa, Romanov and F1 ewes on accelerated lambing management. Small Rumin Res, 32:167-172.

Morris ST. 2009. Economics of sheep production. Small Rumin Res, 86:59-62.

Ocak S, Emsen E, Koycegiz F, Kutluca M, Onder H. 2009. Comparison of placental traits and their relation to litter size and parity weight in sheep. J Anim Sci, 87:3196-3201.

Ricordeau GJ, Thimonier JP, Poivey MA, Driancourt MT, Hochereu-De-Reviers, Tchamitchian L. 1990. INRA research on the Romanov sheep breed in France: a review. Livest Prod Sci, 24:305-332.

Sierra I. 1989. The Salz Sheep Breed [in Spanish]. Zaragoza, Spain: Ibercaja Press. 95 pp.

Vesely JA, Swierstra EE. 1986. Reproductive parameters of crossbred ewe lambs sired by Romanov, Finish Landrace, Dorset and Western range rams. $J$ Anim Sci, 62:1555-1562. 